DOI 10.37882/2223-2982.2020.04.17

\title{
ЭТНОКУЛЬТУРНЫЕ ОСОБЕННОСТИ ИНТЕЛЛЕКТУАЛЬНОГО ВОСПИТАНИЯ ДЕТЕЙ
}

\section{ETHNOCULTURAL FEATURES OF THE INTELLECTUAL EDUCATION OF CHILDREN \\ I. Muskhanova \\ A. Yahyaeva}

Summary: This article analyzes the development of children's intellectual abilities in an ethnocultural educational environment. It is emphasized that communication, language, family, and learning are the structural components of the development of children's intellectual abilities.

Keywords: intellectual abilities, development, family, children, ethnocultural educational environment.
Мусханова Исита Вахидовна,

Д.п.н., профессор, ФГБОУ ВО ЧеченскИй государственный педагогический университет, vinter_65@mail.ru

Яхьяева Амина Хасановна,

К.п.н., дочент, ФГБОУ ВО Чеченский государственный педагогический университет amina.sp@mail.ru

Аннотация: В данной статье проводится анализ развития интеллектуальных способностей детей в этнокультурной образовательной среде, подчеркивается, что структурными компонентами развития интеллектуальных способностей детей выступают общение, язык, семья, обучение, рассматриваются категории «Лела хаар», «Кхетам», «Хьекъал».

Ключевые слова: интеллектуальные способности, развитие, семья, дети, этнокультурная образовательная среда.

Воздействие этнокультурной образовательной среды на развитие интеллектуальных способностей рассматривалось в трудах зарубежных и отечественных педагогов, психологов: К.А. Гельвеция, Я.А. Коменского, Р. Оуэна, Ж.Ж. Руссо, П.Ф. Каптерева, О.Б. Крупениной, Л.Н Толстого, В.П. Шульгина и др. Современные исследования проблемы отмечаются в работах Г.Н. Волкова, О.Д. Мукаевой, А.Б. Панькина, И.В. Мусхановой.

С точки зрения П.Ф. Каптерева педагогический процесс должен быть обусловлен национальными ценностями (язык, традиции, обычаи, быт), нужно развивать в детях этническую идентичность [2].

В культурно-исторической концепции Л.С. Выготского отмечается значимость интеллектуального развития детей, которое основывается на родной культуре. Национальное самосознание, этническая идентичность, навыки межнационального общения - являются показателем развития интеллектуальных способностей детей [1]. А.Б. Панькин в работе [3] этнокультурную среду рассматривает как средство воспитания, развития детей.

В чеченской народной педагогике особое место занимает интеллектуальное и умственное воспитание личности. С самого раннего детства ребенок в чеченском обществе находится в условиях обучения: как вести себя по отношению к родителям, взрослым, ровесникам и т.д. [4].

Формирование этнокультурной личности происходит, в первую очередь, в семье. На ранних этапах социализации ребенок усваивает модель поведения, демонстрируемую взрослыми. Интеллектуальное воспитание связано с умением вести себя [6]. 
Развитие интеллектуальных способностей в этнопедагогике чеченцев имеет большое значение для решения проблем воспитания в современной школе. Опыт народной педагогики чеченцев отражает бытовые условия, менталитет и национальные чувства народа. Народная педагогика чеченцев представляет собой опыт традиционного воспитания, накопленный на протяжении длительного времени. Следует отметить, что главным в развитии и воспитании чеченцев - закрепление у детей уважение, чувства долга и чести, скромность и т.д. Важным условием жизнедеятельности чеченского народа является хозяйственная деятельность. В этнопедагогике чеченцев воспитание - это не только трудовые навыки и умения, но также культура общения, творческая самореализация. Таким образом, народная педагогика отражает опыт воспитания, образования и бытовой уровень народа, народная педагогика теоретически не осмыслена. А этнопедагогика - это теоретическое, обобщенное осмысление народной педагогики.

На наш взгляд, развитие интеллектуальных способностей детей в этнокультурной образовательной среде - способность к успешной адаптации учебном, трудовом коллективе, а также в условиях инокультурного воздействия. Структурными компонентами развития интеллектуальных способностей детей в этнокультурной образовательной среде являются: язык, национальное самосознание, традиции, обычаи, система ценностей, нормы, этническая идентичность. В этнокультурной образовательной среде чеченцев уровень развития интеллектуальных способностей детей определяется категорией «Лела хаар» - умения себя вести в обществе, дома, в гостях. «Лела хаар» взаимосвязано с категориями «Кхетам» - разум, сознание и «Хьекъал» - ум, интеллект.

Понятие «Кхетам» (разум, сознание) чеченцы понимают как объем знаний, умение анализировать, уровень развития мышления. «Хьекъале стаг» (умный человек) доложен обладать такими качествами как настойчивость в познавательной деятельности, самостоятельность, умение применять знания на практике, инициативность и настойчивость. У чеченцев бытует мнение, что "хьекъал» (ум) во многом обусловлен наследственными факторами. Понятие «Кхетам» (сознание) шире, чем хьекъал (ум). «Кхетам болу стаг» - это человек, имеющий глобальное мышление, умеющий не только анализировать, но и прогнозировать события. C «кхетам» связано умение следовать собственным этническим традициям, адаптироваться в инокультурной среде. Кхетам включает в себя не только пытливый ум, наблюдательность и смекалку, но это еще показатель собственной организации интеллектуального и личностного развития.

В чеченском обществе корреляция «Кхетам» и «Хьекъал» наглядно демонстрируется поведенческим компонентом (Лела хаар) (умение вести себя). У чеченцев «Лела хаар» проявляется и в коммуникативном поведении, которая строго регламентирована по принципу: старшиймладший; мужчина-женщина; родители-дети; муж-жена и т.д. Бестактность, допущенная в перечисленной нами иерархии, позволяет выносить оценочные суждения о «Лела хаар». Совокупность категорий «Лела хаар», «кхетам», «хьекъал» формирует представление чеченцев о совершенной личности, наивысшей нравственности степень, которой проявляется в «Нохчалла» (чеченскость).

Как известно, семейное воспитание, ориентированное на формирование смысловой сферы, нравственных норм и жизненных принципов, является определяющим в жизни каждого человека. В контексте вышесказанного огромное значение имеет этнопедагогика семьи, где в наибольшей мере представлены духовные и, прежде всего, идейно-нравственные ценности народа, идеалы добра и красоты, нравственно - этическое восприятие им действительности: отношение к семье, к роду как к ближайшему окружению человека, этносу и межэтнические взаимоотношения [5].

Таким образом, этнокультурная образовательная среда формирует знания в области родной культуры, культуры других народов, развивает этнокультурную идентичHOCTь.

1. Выготский Л.С. Собрание сочинений. Т. 3. -М., 1983.

2. Каптерев П.Ф. Избранные педагогические сочинения. - М., 1982

3. Панькин А.Б. Этнокультурная коннотация образования: монография. Элиста: Изд-во Калм. Гос. Ун-та, 2009. С.380

4. Мусханова И.В. Использование этнопедагогических знаний чеченцев в гуманистическом воспитании молодежи.// Монография. Назрань, 2009. 162 с.

5. Мусханова И.В. Психолого-педагогические условия формирования этнокультурной личности в семье. Журнал «Психология и психотехника». 2011. № 5 (32). C. 81-84.

6. Яхьяева А.Х. Интеллектуальное развитие детей в чеченской семье. Сборник: Актуальные проблемы современной семьи: теория и практика Материалы Всероссийской научно-практической конференции (с международным участием). 2016. С. 260-265. 